\title{
“BREAKING THE SILENCE”: LOCAL PERCEPTIONS OF SLUM TOURISM IN DHARAVI
}

\author{
NIECK SLIKKER* AND KO KOENS† \\ *International Tourism Management, Stenden University of Applied Sciences, Leeuwarden, Netherlands \\ †Academy of Hotel and Facility Management, NHTV Breda University of Applied Sciences, \\ Breda, Netherlands \\ $\ddagger$ School of Tourism and Hospitality, Faculty of Management, University of Johannesburg, \\ Johannesburg, South Africa
}

\begin{abstract}
Slum tourism has been criticized for potentially exploiting the communities it visits. While the daily life of residents is the primary attraction of slum tourism, they do not receive any remuneration. Given the heated debate surrounding this topic, it is surprising that the perspective of residents remains largely unknown. This article aims to address this lacuna, by providing insights into the perceptions that residents have on slum tourism in Dharavi slum, India. It is unique in that it explicitly addresses host perceptions towards slum tourism enterprises as well as charitable activities funded through slum tourism. Insights were gained through 74 semistructured interviews, conducted in the most visited areas of the slum. Four different resident perspectives are recognized: apprehensive, positive, indifferent, and skeptical. Over time, residents in Dharavi become less excited by the presence of tourists, but they do not develop a negative attitude to them. Although residents are not without criticism of tourism, and there is a lack of knowledge on tourism's contribution to community development projects, they do not view tourism as exploitative. The struggle for Dharavi will be to ensure tour operators will continue to operate in a way sensitive to the local community, as tourist numbers and competition increases.
\end{abstract}

Key words: Slum tourism; Dharavi; Local perceptions; Resident perspective; Tourism ethics

\section{Introduction}

Twenty years after its onset, international slum tourism-where tourists from the global North visit impoverished urban areas in the global Southremains a highly controversial phenomenon (Frenzel
\& Koens, 2012; Steinbrink, 2012). Reports on the concept in popular media almost inevitably result in an ethical discussion regarding its presumed exploitative nature, in which local community members are misrepresented and receive only limited benefits (see, e.g., CCTV America, 2014; Hanrahan, 2013). 
For example, the Indian government until recently discouraged slum tourism, as it was viewed to misrepresent the country and undermine the status of other tourism attractions (Basu, 2012). Other countries take a more positive stance to slum tourism development though. In South Africa government supports township tourism for its potential of providing economic benefits and stimulating local economic development (Koens \& Thomas, 2015).

Given the diversity in perspectives regarding the impact of slum tourism on local residents, it is surprising how little research has focused on the perception of the host community. There are plenty of examples of work on host perceptions in other contexts (Nunkoo, Smith, \& Ramkissoon, 2013), but in slum tourism, where the impoverished living conditions of host community members are a primary attraction, such work is missing (Burgold, Frenzel, \& Rolfes, 2013; Rolfes, 2010). Slum tourism arguably gives voice to slum tourism residents, but their voice cannot be heard in academic writing. The lack of work on resident perspectives can be attributed to the intensive nature of such research and language barriers between researcher and residents (Freire-Medeiros, 2012; Frisch, 2012). Understandable as these reasons are, it does mean that the host community perspective hardly is taken into account in the debate on ethics in slum tourism.

This article aims to deal with this issue by providing deeper insights into the residents' perceptions towards slum tourism, through a research investigation set in Dharavi, India. More specifically, its objectives are: 1) to investigate differences in perceptions among Dharavi residents and their development over time, and 2) to explore resident perceptions of the "Reality Group," the first and the largest company to organize commercial slum tours in Dharavi. The Reality Group is unique in that it operates as a social enterprise and invests a large share of their profits back into the Dharavi community through a sister NGO called "Reality Gives," as well as other local NGOs. This makes it a suitable company to investigate as it helps provide insights into commercial slum tourism as well as charitable practices related to it.

\section{Appreciating Residents' Perceptions in Tourism}

One of the earliest studies on the relationship between tourism and residents' perceptions comes from Doxey (1975). In his Irridex model he proposed that residents initially are euphoric when tourism comes to an area, and that their support gradually deteriorates until they actively oppose its further development. The trend of increasingly negative attitudes towards tourism has been confirmed in other work, albeit not without qualifications. In particular, it has been argued that there is a negative bias in work on this subject and that positive perceptions remain underreported (McKercher \& Prideaux, 2014). Also, it cannot be assumed that host communities are homogeneous and that their perceptions develop in a linear way over time (Moyle, Croy, \& Weiler, 2010; Nunkoo et al., 2013). To better appreciate host attitudes, it is useful to distinguish between different groups of residents. Where such work has been done, residents' attitudes range from "lovers” to those who "hate" tourism to their community (Williams \& Lawson, 2001). Although results differ per location, in most areas a little under half of the population perceives tourism positively, while up to a third can have a deeply negative perception (Sharpley, 2014).

The fact that the majority of work discusses established tourism destinations in the developed world is a weakness of the current literature (Harrill, 2004). Work on newly emerging destinations in Uganda and Indonesia highlights how the reaction to the initial development of tourism was one of suspicion, anxiety, and fear, rather than excitement, particularly if tourists commit social and cultural blunders (Cole, 1997; Lepp, 2008). Only after residents had acquired a basic understanding of tourism did they become more positive.

Increasingly exchange theory is used to appreciate residents' perceptions (Nunkoo et al., 2013). Exchange theory focuses on "understanding the exchange of resources between individuals and groups in an interaction situation” (Ap, 1992, p. 668). When people engage in an interaction process, their satisfaction with the exchange depends on a perception of the overall outcome (i.e., whether they have gained something of worth through it, be it material, social, or psychological). Placed in a tourism context, this means that "an individual's attitudes toward this industry, and subsequent level of support for its development, will be influenced by his or her evaluation of resulting outcomes in the community" (Andereck, Valentine, Knopf, \& Vogt, 2005, p. 1061). Residents who perceive benefits from tourism or expect benefits 
in the near future are more likely to have positive perceptions than those who do not (Deery, Jago, \& Fredline, 2012; Smith \& Krannich, 1998).

Social exchange theory has proven useful to appreciate host perspectives (e.g., on the subject of community support through financial donations). These have been criticized for focusing only on short-term community gain, without providing long-term benefits (Ashley \& Haysom, 2006; Obalola, 2008). Particularly when donations are used by companies for promotional activities (e.g., to improve brand image or increase sales), residents can start to view the exchange as uneven and local support can dwindle. The same can happen when only certain individuals within the community benefit and others are left behind (Andereck et al., 2005; Mbaiwa, 2005; Polonsky et al., 2013).

Historically, social exchange theory has focused strongly on economic benefits, while social and cultural aspects have remained relatively underdeveloped (McGehee \& Meares, 1998). Although they are becoming more integrated in recent work (e.g., Brida, Chiappa, Meleddu, \& Pulina, 2014; Nunkoo \& Ramkissoon, 2010), this remains a weakness. It has been suggested that, to further theoretical development of social exchange theory, more work is needed on the social and cultural aspects of exchanges, particularly in developing countries (Sirakaya, Teye, \& Sönmez, 2002; Wang \& Pfister, 2008). As discussed below, slum tourism could be a useful setting to do this.

\section{Local Perspectives on Slum Tourism}

Slum tourism is increasingly popular, and in destinations like Cape Town and Rio de Janeiro it has all but become part of mainstream tourism (Frenzel \& Koens, 2012). Although differences can be observed between slum tourism offerings in different localities, one thing that unites them is the importance placed on experiencing local life, as lived by economically poor local residents. More than with other forms of tourism, residents are key to the slum tourism product. This may be why slum tours have come under so much criticism for being voyeuristic and potentially exploitative (Butler, 2012; Chhabra \& Chowdhury, 2012). However, slum tourism operators stress their efforts to contribute to the economic and social progress within the visited community
(Dyson, 2012). While these ideals may be genuine, they can be difficult to operationalize in a context of strong economic pressure and competition (Koens \& Tomas, 2015), and may not be observed as such by the visited communities.

Academic research on host communities in slum tourism literature has primarily focused on direct individual economic benefits. It confirms that community members who gain economically from slum tourism commonly have a positive stance towards it (Duarte, 2010). However, opportunities for economic gain in slum tourism largely remain limited to a minority of the community (Freire-Medeiros, 2012). The opinion of other community members, who do not economically benefit, is not entirely clear. On the whole, they appear tolerant towards tourism, particularly when they feel tourism can stimulate the development of the "slum" in which they live. In a small minority of cases, residents seek out a conversation with tourists, although language barriers commonly mean such conversations have to be mitigated by a guide, thus losing their spontaneity (Meschkank, 2011; Søderstrøm, 2014). Residents do criticize the content of the tours and the sights that are visited (Duarte, 2010; FreireMedeiros, 2012). In particular they have issues with the ways in which slum tourism causes local culture and poverty to be commercialized and exploited for personal financial gains by a minority (Ramchander, 2004), or they complain about invasions of privacy without personal remuneration (Søderstrøm, 2014). There also is a lot of unawareness regarding slum tourism among residents. A study on favela tourism, for example, showed that three quarters of all residents are not fully aware that favela tourism companies are commercial enterprises that make money off visiting their community (Freire-Medeiros, 2012). Possibly, if they were, their perception would be more negative.

While these findings are interesting, they provide only limited analytical insights to the ways in which residents experience slum tourism. Furthermore, work has focused on township and favela tourism, while increasingly popular slums like Dharavi have received much less attention.

\section{Slum Tourism in Dharavi}

The tour operator Reality Tours and Travel (RTT) officially started operating slum tours in Dharavi, 
the largest slum in Mumbai, in 2006. RTT has grown rapidly since then and now provides tours for over 17,000 tourists annually. At the same time a growing number of other, smaller, tour operators and independent guides have become active. While RTT is still a market leader, with an estimated market share of $85 \%$, the number of people using these new slum tour companies is growing, and over 20,000 tourists now visit Dharavi annually. This is a strong increase over the estimated 1,500 to 3,500 tourists visiting the area 5 years ago (Rolfes, 2010). During high season over eight tours per day are run and tourists have become a familiar sight.

We see them daily. We can't be certain if the sun will shine tomorrow. However, one thing is certain; the tourists will surely be there. It's always certain we will see them. (Female, age 26, housewife)

The approximate length of most tours is $3 \mathrm{~km}$ and they cross through multiple nagars (neighborhoods), each with their own community and characteristics. The areas differ in religion, hygiene, public facilities, maintenance, type of industry, size of living space, and more. Slum tourism in Dharavi focuses on the vibrancy of the community, including the "commercial versatility and industriousness of the inhabitants" (Rolfes, 2010, pp. 437-438). While the tours pass through impoverished areas, the narrative is upbeat and aimed at making tourists leave with a more positive picture of the Dharavi community. Also, as the largest company, RTT emphasizes their tours need to be respectful to the local community and they have set up a dress code that tourists need to adhere to (Dyson, 2012).

At the time of the research RTT was the only tour operator in Dharavi to structurally invest its profits into social projects and NGOs that support the community as part of its business model. The Realty Group has founded a sister NGO Reality Gives (RG) to develop this aspect of their work and won a World Responsible Tourism Award in 2012, strengthening its public credentials as a socially responsible company. At the time of conducting the research, RG operated six community support projects themselves, while it also financially supported seven projects run by local NGOs. The Reality Group also deliberately hires people from deprived backgrounds, albeit not only from Dharavi. In this way the company tries to ensure an equal exchange with the community. However, they are largely unaware whether they succeed at this, given that they find it difficult to get feedback from the community (Al Jazeera, 2013).

\section{Methodological Considerations}

This research uses a qualitative approach to explore the perceptions of residents to slum tourism in general as well as to Reality Group. In this way it seeks to go beyond previous work on community perceptions that used exchange theory in combination with a quantitative cross-sectional methodology (Nunkoo et al., 2013; Zhang, Inbakaran, \& Jackson, 2006). The weakness of such work is that it tends to view communities as homogenous entities and that it limits respondents to a particular direction (Beeton, 2006). By employing a qualitative approach, it is possible to have respondents "drive the analysis, rather than the research dictating the focus” (Moyle et al., 2010, p. 360).

Data gathering took place between August and October 2013. Although the research is focused primarily on efforts from the Reality Group, it also takes into account tours from other companies. A total of 74 face-to-face interviews were conducted with adult members of the Dharavi community, who lived or worked along the route of Reality Tours and its attractions. Participants were purposefully sought out to reflect the diversity that exists within the community, although in some cases snowball sampling was employed to gain access. Research was focused on individuals of ages 17 and older, as it was imperative that respondents had a wider perception of things evolving in their communities. None of the respondents were directly involved or financially benefited from tourism, and all gave consent to be interviewed.

Interviews lasted between 30 to 45 minutes. A general interview guide was used to structure the interviews, although respondents were stimulated to talk freely during the interview. Interviews started with a general introduction, following which they were asked about their background and profession. The interview then focused on the moment respondents first noted tourists coming to their neighborhood-commonly just after RTT started operating — and their initial perceptions. After this, 
they were asked how they currently perceive slum tourism to their area, and to reflect on possible changes in their perception. Although it is appreciated that this is not the most reliable way of measuring changing perceptions, it introduces an indicative longitudinal element to the study that helps clarify residents' perceptions. The discussion turned towards the tour operators performing these tours, with an emphasis on RTT and RG. Respondents were asked if they were aware of the different operators, as well as what their thoughts were on the goals and aims of the organizations. When respondents did not know RTT and or RG, their goals and aims were explained, to further fuel the discussion.

Because hardly any respondents spoke English, interviews were conducted with the help of three interpreter guides. The use of an interpreter, in combination with the background of the interviewing researcher (a Caucasian male), is likely to have influenced research results. The following five measures were taken to minimize negative impacts (following Freire-Medeiros, 2012; Gray, 2013; Lepp, 2008; Vanden Berg, 2014). Firstly, potential issues that could arise during interviews were discussed with a variety of local actors. Secondly, the interviewing researcher kept a field diary to continuously reflect on the interview process. Thirdly, the interview guide was translated into Hindi to ensure interviews would be conducted in a similar way. Fourthly, interpreters were given training on the process of conducting an interview. Finally, three trial interviews were held in Dharavi, during which all interpreters were present. In general the research process went well, although the translation from English to Hindi at times somewhat disrupted the flow of the interview, and three respondents were not very fluent in Hindi, which meant questions had to be repeated often.

Analysis of the research was done using a basic grounded approach, although it was informed by an initial understanding of slum tourism and Dharavi. Following Braun and Clarke (2006), interviews were recorded and transcribed in English, after which an initial phase of open coding was performed. Following this, themes based on the most common responses from the interview were recognized, reviewed, redefined, and related back to the literature (Ritchie, Lewis, Nicholls, \& Ormston, 2013).

\section{Dharavi Residents’ Perceptions of Tourism}

When asked how they feel about tourism, most respondents note that they are happy and proud that people are interested in their community. The foreign interest in their way of life is seen as very positive, and respondents believe that tours highlight the positive aspects of Dharavi, rather than focus on the negative aspects of poverty. Respondents generally speak of tourists as well-mannered and they seek to return the favor. In line with Indian cultural reasoning, they treat their "guests" with the highest respect.

\begin{abstract}
I was a bit surprised, because I was wondering why they were coming here. At the same time I thought in the back of my head "He's my guest, he's coming to my country, my place. He's my guest, so similar to a God. So I have to give something to him.” (Male, age 41, owner of a soap factory)
\end{abstract}

One particular aspect that is appreciated is that children now have an opportunity to deal with foreign visitors. Even when interaction is incredibly limited and goes little further than tourists waving and giving greetings, respondents still believe that tourism helps improve the level of English of children. The sweets or biscuits that tourists incidentally hand out are also viewed in a positive light. As one respondent mentions: "when the children are happy because of the tourists, the parents are happy too" (Female, age 26, former catering worker).

It is striking that hardly any respondents mention the potential for individual financial gain or employment as a positive aspect of tourism in Dharavi. Respondents do mention that operators should do more to help the community. They feel it would only be fair for companies to give something back, as they are exploiting the amenities of the community. However, even critical respondents largely have a positive attitude towards tourism to Dharavi. This suggests that, at the moment, the non-economic benefits of tourism provide sufficient benefits for the majority of respondents, to make them perceive tourism positively.

Residents may see tourists on a daily basis, but there is little interaction between the two groups. The limited contact is partially because of language barriers and because the tours are run on a tight schedule, with limited time to stop. On the other hand, residents also note that they are simply too 
busy with work and survival and that interaction with tourists is not really on their agenda.

We are busy with our own work and they are busy with their things. But we are quite happy, because tourists here in India are guests, and guests are treated like gods. (Male, age 65, retired, Maharashtra; Dharavi)

While this interviewee remains positive, there is relatively large group that is indifferent to tourism. They recognize tourism has only limited impact on their lives and do not care whether tourists come or not, as long as they are not bothered by them.

Respondents do recognize that tourism can potentially harm the community. For example, residents express their concern about the safety of the tourists. One industrial area that is visited is not without risk, and tourists could harm themselves when they make their way past or through the various little factories. Owners of factories are afraid tourists might get hurt and that this would result in lawsuits or a police raid. The owners would rather have the tourists not entering the factories, or they would like the guide to ask for permission from the owner first. However, they also feel a sense of moral obligation to show off the hospitality of Dharavi, and do not prevent tour groups from entering.

Tourist safety is not the only worry that residents have about tourism. A minority of respondents believe that tourists stain the name of Dharavi, as poverty and bad hygiene are used for entertainment, or because they fear tourists want to discover illegal activities (e.g., child labor, informal industries).

I thought "Why are they coming here?! What is there to see? They should go to the Gateway of India, or some better place to see.” I just thought they came here to make fun of us, of our living conditions here. (Male, age 35, owner of an aluminium compound factory)

Although, on the whole, residents feel the tours are operated with respect for the community, there are respondents who fear that tour operators deliberately depict Dharavi in a negative way, and that the guides provide tourists with incorrect information, to make the tour appear more spectacular.

I think that the guides are not giving the right information about this place. For example at the toilet over there. Every day only 30 to 50 people use that toilet, but the guide says that more than a thousand people use that toilet. That's false information and we don't like that. (Male, age 20, tailor, Maharashtra; Dharavi)

Contrary to what might have been expected on the basis of earlier research (e.g., Chhabra \& Chowdhury, 2012), residents do not mention they find the tours explicitly voyeuristic. However, they do mention other aspects that relate to this. A specific complaint has to do with the use of photo cameras on tours. Although RTT has a strict camera policy and, for example, does not allow any photography during certain parts of the tours, residents still worry about photography on slum tours. They fear that tourist photos will harm the community. Such sentiments are not unfounded. A photo of the garbage area, which was taken during a tour, once ended up in a newspaper, strongly offending the inhabitants. Also, Papadum producers in one part of Dharavi lost much business after a photo in the media caused outsiders to question the hygiene of their Papadum production.

In spite of the fact that RTT has a tourist dress code, 10 respondents believe that female tourists should wear more appropriate clothing, as their current dress is too revealing (e.g., bare shoulders, bare knees, or too much cleavage).

some women wear appropriate clothing, but many women come here wearing shorts or things like that. So if the guys or our husbands see that, we don't like that. We feel bad then. The men start looking at them and we think "Why can't they dress more like us?” (Females, ages 39, 43, and 44 , housewives)

The idea of appropriate dressing actually may point to a more generational conflict within Dharavi that is exacerbated by tourism. Younger respondents are more positive about the dress code and, in fact, view it as a form of progress. Two respondents even have started to copy the way tourists dress.

After further analysis of the interviews four different perspectives toward tourism have been discerned that captivate the different perceptions: apprehensive, positive, indifferent, and skeptical (Fig. 1). Some respondents found it difficult to remember their initial perceptions of tourism and therefore have, in 15 cases, been classified in multiple categories based upon their recall. While the sample used 


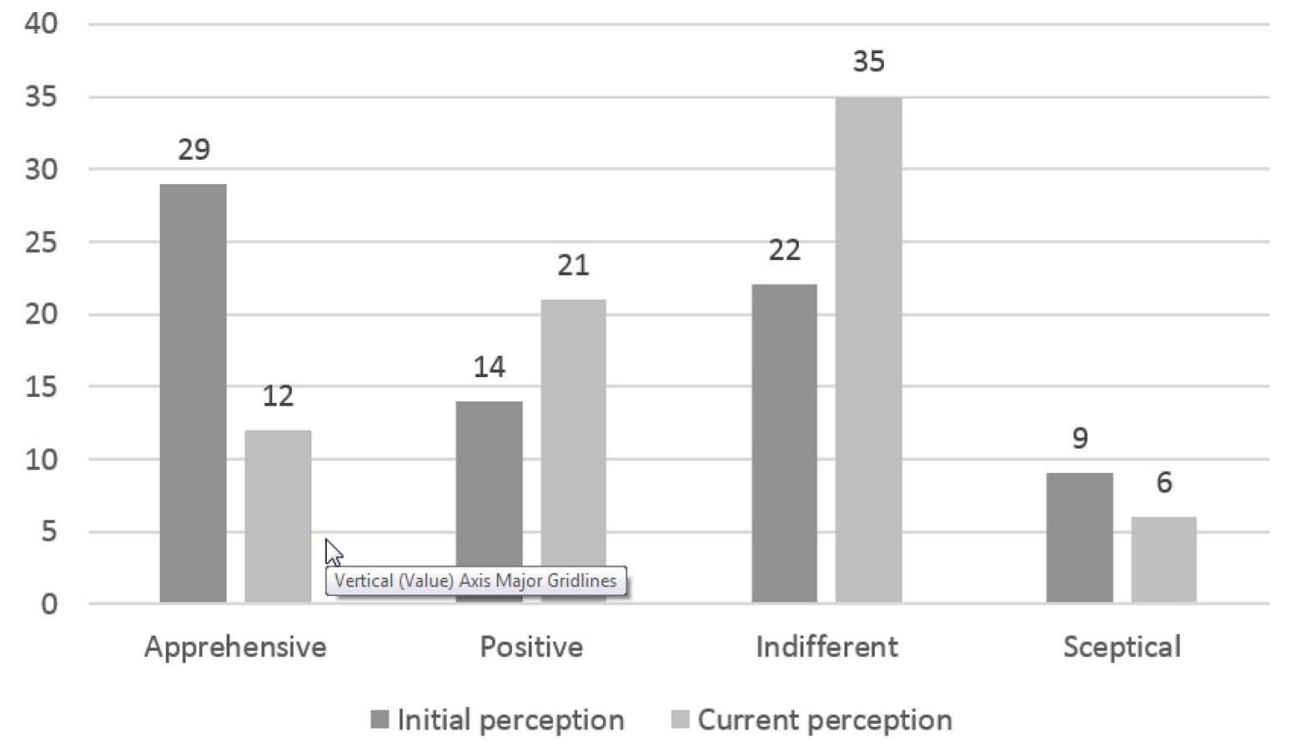

Figure 1. Initial and current perception of respondents to slum tourism in Dharavi (source: research findings).

in this research is not necessarily representative, and the perspectives represent a simplification, they still are useful to indicate how Dharavi residents view tourism. It is also useful to explore how tourism perceptions develop over time.

Residents who display an apprehensive perception emphasize the fact that tourism to Dharavi is unusual. They question its purpose as well as the intention of tourists. A lack of knowledge and familiarity with tourism makes it difficult to appreciate its benefits and drawbacks. This perception is shared by 35 respondents when they first noticed tourism. They recall their first tourist encounter as one of shock; two respondents were even scared. Others were intrigued by the white skin of the tourists, or generally surprised about the fact that tourists would leave their well-established countries to visit a place of poverty. These reactions are similar to those described by Cole (1997) and Lepp (2008) in newly established tourism destinations. The number of people who can be classified as apprehensive at the time of the research has dropped to 12. Largely this can be attributed to a greater knowledge, familiarity, and confidence regarding tourists, due to the increase of tourist numbers.

The first time I was pretty surprised, but if the same thing is going on over and over, it becomes normal. I actually thought that there might be some problem in their own country, so they came to live here. (Male, age 19, student)

The positive perception can be described as one where residents feel happy or proud about tourism coming to Dharavi. Respondents who share this perspective see the tourism exchange as positive. They enjoy seeing tourists, feel tourism brings social benefits, are hopeful that tourism can contribute to a better future for the Dharavi community as a whole, and welcome further tourism development. Although at first sight only 17 respondents approached tourism with an outright positive perception, this number has risen to 21 . The number has risen mainly due to respondents who previously had an apprehensive approach gaining confidence in tourism, although some initially positive respondents had become indifferent.

When residents have an indifferent perception to tourism, they choose to ignore the tourists or tourism development. They know about tourism, but do not see it bringing themselves many benefits. Not excited about tourism, respondents with an indifferent perception focus on other aspects of their lives (i.e., making a living). As long as it does not negatively affect their lives though, they do not see it as particularly negative either. Twenty-six respondents 
had an indifferent perception when they first encountered tourism in Dharavi, but this number has grown to 35 at the time of the research. Although this growth can mostly be attributed to people becoming less apprehensive, a small number of residents who initially had positive and skeptical perceptions also have become indifferent over time.

Residents with a skeptical perception are unhappy and with the impact that tourism has on their community. Although they are not actively trying to disrupt tourism, they are suspicious of the quick growth of tourist numbers and fear that the benefits for the community may no longer outweigh the disadvantages. The number of respondents with a skeptical perception has dropped from 11 when they first encountered tourism in Dharavi to 7 at the time of the research. Those with a skeptical perspective at the time of the research relate this mainly to occurrences of unwanted photography or negative media attention.

Overall, looking at the development of perceptions of tourism over time, the number of respondents with an apprehensive and skeptical perception has gone down. A greater number of respondents are now positive, but the number of participants with an indifferent perception has particularly risen. To an extent this large number of indifferent residents is surprising, as the Reality Group emphasizes its efforts to actively support and benefit the local community. The next section therefore focuses on the perception of the Reality Group and its charitable work.

\section{Perceptions of the Reality Group and its Charitable Work}

Local awareness of the Reality Group is very low. Even though RTT tries to distinguish itself clearly from its competitors, and guides of RTT wear company clothing with the name and logo of the company, only five respondents recognize them as a separate company. This reflects the situation in the Brazilian favelas, where residents also had great difficulty differentiating between tour operators (Freire-Medeiros, 2012). It does mean that malpractices of other companies may reflect upon RTT.

When RTT was started, its owner went into Dharavi to get people on board and support tourism by discussing the potential benefits that tourism could bring to the community:
Krishna (founder) also came here and told the people that if he could show the tourists this area, then maybe eventually this area would get developed. (Male, age 26, clothing designer)

Suggestions like these may have raised the hopes of residents and may be one reason for the increasing indifference among residents who do not see much evidence for the development of the area. Particularly, RG is very much an unknown entity, with only 16 respondents recognizing its projects and only 5 linking the work they do to slum tourism activities. This lack of awareness caused multiple respondents to argue that RTT does nothing to support the community.

When respondents were explained about the connection between the two parts of the Reality Group and the different projects, reactions were mixed. Most reacted very positively and appreciate RTT as a company much more because of it.

\footnotetext{
Yes, in my mind a lot has changed. Many companies just earn their money and run away. But this is a company that does something for the community, even if it is very little. Whoever will know about this company and the NGO, will pray for this company that they will grow. It's a very good thing what they are doing. (Male, age 23, wax printing employee)
}

Others, however, remain wary, wanting to see proof of the projects. One respondent actively questions the underlying motivation of the Reality Group and sees the community work only as a marketing ploy. Others would not go this far, but do argue they hear too little about the projects, and feel that the Reality Group needs to do more to promote what they do. A group of young adult respondents are annoyed that RTT has involved them too little in their charitable activities, even when tourists have been brought to "their" places. Others state that residents are involved too little in the assessments of current or future projects. Similarly, they remark that more transparency should be offered about how funding is used to rule out corruption.

Yes, these projects are a very good way to give back to the community. But many people don't know about these projects. So they have to go into the community and tell them about it. People are too busy with their own work and they don't 
care what you have to tell them. You have to build relationships with them. (Male, age 30, yoga therapist)

It is not just respondents with a skeptical perception to tourism to Dharavi that are wary of the impact of Reality Gives. It is also mentioned by those with other perceptions. One respondent mentions the high level of distrust in the community is at least partially caused by dissatisfaction with the government. Politicians have regularly come to Dharavi with false promises. This has not only caused residents to lose faith in politics, but it has also reduced their trust in the work of NGOs and charitable companies. To overcome this, respondents argue that the impact of projects has to be much more visible within the community.

Looking at individual projects, the most valued projects relate to education, employment, and health. Perhaps unsurprisingly, female respondents particularly value projects aimed at empowering women or projects that make the life of primary carers easier (e.g., childcare support). When asked what kinds of projects respondents would further desire, residents point to the need for even more education and health projects. Additionally, they stress the need for action improving the cleanliness of Dharavi, even though they are aware that this is largely the responsibility of the government. Although little mention is made of support projects that directly involve tourists or tourism, residents once again emphasize the need for greater visibility of the Reality Group in Dharavi.

I think there should be a Reality Tours \& Travel or Reality Gives office in the slum, so that whatever problem we have, we can go to this office to talk to them. (Male, age 23, factory worker)

\section{Discussion}

Findings highlight a diverse range of opinions and perceptions of tourism. Differences exist between community members, reflecting the diversity that characterizes the Dharavi community. For example, tourists are generally perceived as friendly, interesting, well behaved, and a sign of progress, but some feel they also cause offense at times. Resident perspectives can be categorized into four main perceptions: apprehensive, positive, indifferent, and skeptical.
This categorization shares a resemblance with classifications proposed by other authors (Diedrich \& García-Buades, 2009; Doxey, 1975; Lepp, 2008). A difference is that perceptions are not viewed as fixed, but they can instead differ among community members and they can change over time.

If residents have a positive perception of tourism in Dharavi, this is commonly not directly related to seeking or expecting individual economic benefits, even though they do emphasize the importance of developing the Dharavi community. Looking at this from a wider social perspective, this fits with the general mentality of Dharavi, which is largely based on communal self-reliance in the face of largely absent or ineffective public governance structures (Roy, 2011). Respondents greatly value the social benefits of tourism. They are proud to show off their neighborhood, enjoy the positive attention, and believe in the educational potential of tourism. Other respondents had a form of "live and let live" perspective on tourism. They did not see tourism bring any great benefits, but as long as it does not bring too many negatives, they do not mind its presence. Given these circumstances, they are reluctant to waste energy on it, and they feel they can barely exert influence anyway. This finding is similar to favela tourism (Freire-Medeiros, 2012), but contrasts with Lepp's (2008) more positive notion among residents in a small village in Uganda. The acceptance of tourism should therefore also not be mistaken for unequivocal support. Complaints can be heard, and, if slum tourism does not take into account the perspective of residents and involve them in the growth of tourism, the overall positive perception to tourism can change. To avoid such a potential situation, transparency of slum tourism companies should be promoted and the support and involvement of community members should be stimulated (Coles, Fenclova, \& Dinan, 2013; Moyle et al., 2010).

The overall perception in Dharavi is more positive than commonly observed in other research. After an initial phase of apprehension, the majority of residents are now positive or relatively indifferent to tourism. Only a small group is skeptical and, at this point in time, no one openly opposes and acts against further tourism development. In a way these results provide a counterweight to the rather negative stance in tourism research against the social impacts of 
tourism (McKercher \& Prideaux, 2014). They show that, although trends towards certain perceptions can be observed, no single perception is shared within a community nor is the development of these perceptions strictly linear and negative, as proposed in Doxey's (1975) Irridex or similar models.

Respondents feel somewhat disappointed with the lack of community development, even when they have an overall positive perception of tourism. This is surprising, given that the Reality Group works hard to ensure slum tourism provides net benefits to the community and Reality Gives runs and supports multiple projects that aim at uplifting the community. However, the main issue is to make residents aware of these policies and projects and involve them more. Few residents make the connection between the commercial tours and the community work done through Reality Gives. Greater awareness on this matter is likely to increase positive perceptions.

Residents also have great difficulty discerning RTT tours from their competitors. Up to now new businesses have been mainly started by former guides of RTT. They largely adhere to a similar etiquette in their tours, but they are more lenient on camera and clothing policies. However, it is precisely these issues that respondents believe are key negative aspects from tourism. As such, they should not be ignored if the aim is to maintain a positive perception among residents.

\section{Concluding Thoughts}

This research is the first to explicitly address relations and host perceptions towards slum tourism enterprises in India and their charitable activities. As a contribution to research, it provides qualitative insights into the host perspective to a newly developing destination in the global South, whereas the majority of work on host perceptions has taken place in the developed world and has been quantitative in nature (Deery et al., 2012; Nunkoo et al., 2013). A diverse range of perceptions has been unearthed that reflect the diversity in "economic well-being, social background, cultural and religious heritage and regional identities" that can be observed in Dharavi (Basu, 2012, p. 78).

The research contributes to the theoretical development of social exchange theory by reflecting on the importance of social and cultural benefits. Pride about foreign interest, potential opportunities for children's education, respectful narratives regarding the community, and the possibility to instigate change in society all were viewed as benefits, while inappropriate clothing and photography and potential danger for tourists were important disadvantages. Taking all things into consideration, results from this research suggest that residents in Dharavi, at the moment, do not recognize tourism as voyeuristic and exploitative. They appreciate benefits and costs of tourism and currently view their tourism exchanges more positive than negative. Whether or not this remains the case will depend on the methods of operation of the organizations that pursue slum tourism activities.

Given the current community perception of tourism, the Reality Group is to be commended for trying to create a triple-win situation in which tourist, community, and company needs are met. However, with the changing nature of slum tourism in Dharavi, and an increase in competition, recommendations can be made to make their work more effective. Up to now the Reality Group is far from fully immersed in community and their efforts to improve community development remain largely unknown. Residents argue for greater involvement and transparency, confirming that 'there is a definite need to increase the scope of community participation in slum tourism' (Basu, 2012, p. 78). Earlier research revealed that a lack of consultancy with local residents evidently leads them to become less willing to interact and exchange with tourists (Moyle et al., 2010). A greater focus on local education and promotion of what RTT stands for can therefore be recommended. Unless a concerted effort is made to engage with residents, there is a strong risk that perceived tourism drawbacks will increase.

This research was one of the first to investigate residents' perceptions of slum tourism. As such it has used a largely exploratory, qualitative approach. This allowed for a rich picture of the perceptions of Dharavi residents. It would be useful to take a similar approach to slum tourism in other destinations, both more advanced and newly emerging. Regarding the latter, unfortunately, the development of slum tourism had to be measured using a retrospective method in this research. Given the fact that slum tourism developments are rapidly happening 
in different parts of the globe, it provides an excellent platform to investigate residents' perceptions in emerging destination first hand and further develop theorizing on the matter.

\section{References}

Al Jazeera. (2013, June 10). Slum tourism. The Stream. Al Jazeera. Retrieved from http://stream.aljazeera.com/ story/201306112246-0022819

Andereck, K. L., Valentine, K. M., Knopf, R. C., \& Vogt, C. A. (2005). Residents' perceptions of community tourism impacts. Annals of Tourism Research, 32(4), 1056-1076.

Ap, J. (1992). Residents' perceptions on tourism impacts. Annals of Tourism Research, 19(4), 665-690.

Ashley, C., \& Haysom, G. (2006). From philanthropy to a different way of doing business: Strategies and challenges in integrating pro-poor approaches into tourism Business. Development Southern Africa, 23(2), 265-280.

Basu, K. (2012). Slum tourism: For the poor, by the poor. In F. Frenzel, K. Koens, \& M. Steinbrink (Eds.), Slum tourism: Poverty, power and ethics (pp. 66-82). London: Routledge.

Beeton, S. (2006). Community development through tourism. Collingwood, Australia: Landlinks Press.

Braun, V., \& Clarke, V. (2006). Using thematic analysis in psychology. Qualitative Research in Psychology, 3(2), 77-101.

Brida, J. G., Chiappa, G. D., Meleddu, M., \& Pulina, M. (2014). A comparison of residents' perceptions in two cruise ports in the Mediterranean Sea. International Journal of Tourism Research, 16(2), 180-190.

Burgold, J., Frenzel, F., \& Rolfes, M. (2013). Editorial: Observations on slums and their touristification. DIE ERDE-Journal of the Geographical Society of Berlin, 144(2), 99-104.

Butler, S. R. (2012). Curatorial interventions in township tours: Two trajectories. In F. Frenzel, K. Koens, \& M. Steinbrink (Eds.), Slum tourism: Poverty, power and ethics. London: Routledge.

CCTV America. (2014, April 1). CCTV insight: Cartagena, a tale of two cities. Retrieved from http://www.cctvamerica.com/2014/04/01/cctv-insight-cartagena-a-taleof-two-cities

Chhabra, D., \& Chowdhury, A. (2012). Slum tourism: Ethical or voyeuristic. Tourism Review International, 16(1), 69-73.

Cole, S. (1997). Anthropologists, local communities and sustainable tourist development. In M. Stabbler (Ed.), Tourism and sustainability: Principles to practice (pp. 219230). Oxford: CABI.

Coles, T., Fenclova, E., \& Dinan, C. (2013). Tourism and corporate social responsibility: A critical review and research agenda. Tourism Management Perspectives, 6, 122-141.

Deery, M., Jago, L., \& Fredline, L. (2012). Rethinking social impacts of tourism research: A new research agenda. Tourism Management, 33(1), 64-73.
Diedrich, A., \& García-Buades, E. (2009). Local perceptions of tourism as indicators of destination decline. Tourism Management, 30(4), 512-521.

Doxey, G. V. (1975). A causation theory of visitor-resident irritants: Methodology and research inference. In The impact of tourism: The Travel Research Association, Sixth Annual Conference Proceedings (pp. 195-198). San Diego, CA: Travel Research Association.

Duarte, R. (2010). Exploring the social impacts of favela tourism: An insight into the residents'view. M.Sc. thesis, Wageningen University, Wageningen.

Dyson, P. (2012). Slum tourism: Representing and interpreting "reality" in Dharavi, Mumbai. Tourism Geographies, 14(2), 254-274.

Freire-Medeiros, B. (2012). Favela tourism: Listening to local voices. In F. Frenzel, K. Koens, \& M. Steinbrink (Eds.), Slum tourism: Poverty, power and ethics. London: Routledge.

Frenzel, F., \& Koens, K. (2012). Slum tourism: Developments in a young field of interdisciplinary tourism research. Tourism Geographies, 14(2), 195-212.

Frisch, T. (2012). Glimpses of another world: The favela as a tourist attraction. Tourism Geographies, 14(2), 320-338.

Gray, D. E. (2013). Doing research in the real world. London: Sage.

Hanrahan, M. (2013, May 8). Slum tourism: shanty town tours in Brazil, India, South Africa give travelers glimpse at poverty; raise ethical questions. Retrieved September 5 , 2014, from http://www.huffingtonpost.com/2013/05/08/ slum-tourism-brazil-india-south-africa_n_3237489.html

Harrill, R. (2004). Residents' attitudes toward tourism development: A literature review with implications for tourism planning. Journal of Planning Literature, 18(3), 251-266.

Koens, K., \& Thomas, R. (2015). Is small beautiful? Understanding the contribution of small businesses in township tourism to economic development. Development Southern Africa, 32(3), 320-332.

Lepp, A. (2008). Attitudes towards initial tourism development in a community with no prior tourism experience: The case of Bigodi, Uganda. Journal of Sustainable Tourism, 16(1), 5-22.

Mbaiwa, J. E. (2005). Enclave tourism and its socioeconomic impacts in the Okavango Delta, Botswana. Tourism Management, 26, 157-172.

McGehee, N. G., \& Meares, A. C. (1998). A case study of three tourism-related craft marketing cooperatives in Appalachia: Contributions to community. Journal of Sustainable Tourism, 6(1), 4-25.

McKercher, B., \& Prideaux, B. (2014). Academic myths of tourism. Annals of Tourism Research, 46, 16-28.

Meschkank, J. (2011). Investigations into slum tourism in Mumbai: Poverty tourism and the tensions between different constructions of reality. GeoJournal, 76, 47-62.

Moyle, B., Croy, W. G., \& Weiler, B. (2010). Community perceptions of tourism: Bruny and Magnetic Islands, Australia. Asia Pacific Journal of Tourism Research, 15(3), 353-366. 
Nunkoo, R., \& Ramkissoon, H. (2010). Small island urban tourism: A residents' perspective. Current Issues in Tourism, 13(1), 37-60.

Nunkoo, R., Smith, S. L. J., \& Ramkissoon, H. (2013). Residents' attitudes to tourism: A longitudinal study of 140 articles from 1984 to 2010. Journal of Sustainable Tourism, 21(1), 5-25.

Obalola, M. (2008). Beyond philanthropy: Corporate social responsibility in the Nigerian insurance industry. Social Responsibility Journal, 4(4), 538-548.

Polonsky, M., Hall, J., Vieceli, J., Atay, L., Akdemir, A., \& Marangoz, M. (2013). Using strategic philanthropy to improve heritage tourist sites on the Gallipoli Peninsula, Turkey: Community perceptions of changing quality of life and of the sponsoring organization. Journal of Sustainable Tourism, 21(3), 376-395.

Ramchander, P. (2004). Towards the responsible management of the socio-cultural impact of township tourism. Ph.D. thesis, University of Pretoria, Pretoria.

Ritchie, J., Lewis, J., Nicholls, C. M., \& Ormston, R. (Eds.). (2013). Qualitative research practice: A guide for social science students and researchers (2nd ed.). Thousand Oaks, CA: Sage Publications Ltd.

Rolfes, M. (2010). Poverty tourism: Theoretical reflections and empirical findings regarding an extraordinary form of tourism. GeoJournal, 75(5), 421-442.

Roy, A. (2011). Slumdog cities: Rethinking subaltern urbanism. International Journal of Urban and Regional Research, 35(2), 223-238.

Sharpley, R. (2014). Host perceptions of tourism: A review of the research. Tourism Management, 42, 37-49.
Sirakaya, E., Teye, V., \& Sönmez, S. (2002). Understanding residents' support for tourism development in the central region of Ghana. Journal of Travel Research, 41(1), 57-67.

Smith, M. D., \& Krannich, R. S. (1998). Tourism dependence and resident attitudes. Annals of Tourism Research, 25(4), 783-802.

Søderstrøm, J.A. (2014). Responsible practice for township tourism. An exploration of stakeholders' opinions, commitments, actions and expectations in the township of Langa, Cape Town. Presented at Destination Slum! 2: New Developments and Perspectives in Slum Tourism Research, Potsdam.

Steinbrink, M. (2012). “We did the slum!”-Urban poverty tourism in historical perspective. Tourism Geographies, 14(2), 1-22.

Vanden Berg, T. M. (2014). An inquiry into Jamaican perspectives on tourism. Tourism Culture \& Communication, 14(2), 103-115.

Wang, Y. A., \& Pfister, R. E. (2008). Residents' attitudes toward tourism and perceived personal benefits in a rural community. Journal of Travel Research, 47(1), 84-93.

Williams, J., \& Lawson, R. (2001). Community issues and resident opinions of tourism. Annals of Tourism Research, 28(2), 269-290.

Zhang, J., Inbakaran, R. J., \& Jackson, M. S. (2006). Understanding community attitudes towards tourism and host-guest interaction in the urban-rural border region. Tourism Geographies, 8(2), 182-204. 
Copyright of Tourism Review International is the property of Cognizant Communication Corporation and its content may not be copied or emailed to multiple sites or posted to a listserv without the copyright holder's express written permission. However, users may print, download, or email articles for individual use. 